\title{
PENULISAN ARTIKEL ILMIAH MAHASISWA SEMESTER ENAM FAKULTAS KEGURUAN DAN ILMU PENDIDIKAN UNIVERSITAS MUHAMMADIYAH BUTON
}

\author{
Cecep Nuryadin ${ }^{1}$, Agus Salim ${ }^{2}$, Ardy Lestary Awaludin $\mathrm{R}^{3}$
}

Fakultas Keguruan dan Ilmu Pendidikan Universitas Muhammadiyah Buton Jl. Betoambari No. 36 Kota Baubau, 93721, Indonesia.

Email: cecep.nuryadin@umbuton.ac.id

\begin{abstract}
Abstrak
Keberadaan Peraturan Menteri Pendidikan Nasional No. 22 tahun 2011 tentang Masalah Berkala Ilmiah, dan Surat Edaran Direktorat Jenderal Pendidikan Tinggi Kementerian Pendidikan dan Kebudayaan Republik Indonesia Nomor 152 / E / T / Januari 2012 tentang kewajiban mempublikasikan karya ilmiah termasuk kewajiban mahasiswa sarjana untuk membuat artikel dan mempublikasikannya dalam jurnal ilmiah. Sejauh ini, artikel yang ditulis oleh siswa dipandu oleh pengawas tesis atau penguji tesis belum sepenuhnya memenuhi standar yang ada. Ada banyak ketidakcocokan dalam tulisan yang ditulis oleh siswa. Ini juga akan lebih merepotkan dan proses yang panjang bagi siswa dan manajer jurnal ilmiah di fakultas. Tujuan yang ingin dicapai dalam kegiatan pengabdian masyarakat ini adalah untuk: (1). Peserta pelatihan dapat memahami prosedur penulisan artikel ilmiah, (2). Peserta pelatihan mampu melakukan penulisan ilmiah, (3). Peserta pelatihan dapat memahami aturan dalam bentuk artikel ilmiah di Fakultas Keguruan dan Ilmu Pendidikan: (1) Kegiatan pelatihan dan pendampingan penulisan artikel ilmiah untuk mahasiswa Fakultas Keguruan dan Ilmu Pendidikan di Universitas Muhammadiyah Buton telah dilaksanakan dengan baik hasil dengan peningkatan skor tes rata-rata $20 \%$ dan penguasaan teori dengan kategori Sangat Baik di 30\% dan Baik di 70\%, (2). Target audiens yang dipilih dalam kegiatan pengabdian masyarakat ini memiliki antusiasme yang tinggi untuk mengikuti semua kegiatan hingga selesai dan dianggap mampu mentransmisikan pengetahuan mereka kepada orang lain.
\end{abstract}

\section{Kata Kunci: Penulisan, Artikel Ilmiah}

\section{A. Pendahuluan}

Mahasiswa merupakan insan akademik, tentu tidak akan terlepas perannya sebagai insan ilmiah. Hasil karya yang diciptakan memiliki nilai etis dan tetap pada tataran konsep keilmiahan. Secara akademik, mahasiswa dapat menyandang 
gelar kesarjanaan bila yang bersangkutan telah menyelesaikan karya tulis dalam wujud skripsi yang dalam struktur kurikulum berada pada semester akhir. Dalam perkembangannya, hasil penelitian yang berbentuk tugas akhir atau dalam hal ini adalah skripsi tersebut tidak hanya sebatas lembaran tulisan yang dijilid rapi kemudian di museumkan dalam tatanan kearsipan yang ada. Terlepas itu semua, hasil karya dalam bentuk tulisan tersebut selayaknya dipublikasikan demi pengembangan suatu karya. Meski bagaimanapun karya seseorang harus dihargai, sebagaimana karya tersebut mampu menjadi bahan kajian ataupun pengembangan untuk karya orang lain juga terutama demi pengembangan keilmuan. Selain itu, dengan adanya publikasi, maka hal tersebut dapat meminimalisir dan menghindari adanya tumpang tindih kegiatan plagiatisme.

Adanya Peraturan Menteri Pendidikan Nasional Nomor 22 Tahun 2011 tentang Terbitan Berkala Ilmiah, dan Surat Edaran Direktorat Jenderal Pendidikan Tinggi Kementerian Pendidikan dan Kebudayaan Republik Indonesia Nomor 152/E/T/ bulan Januari 2012 tentang kewajiban publikasi karya ilmiah diantaranya adalah kewajiban mahasiswa S1 untuk membuat artikel dan menerbitkannya di jurnal ilmiah. Sedangkan mahasiswa S2 diwajibkan menerbitkan artikel ilmiah di jurnal nasional yang terakreditasi, mahasiswa S3 diwajibkan memasukan artikelnya yang diterima untuk diterbitkan ke jurnal internasional. Menindaklanjuti kondisi tersebut,

Dalam rangka meningkatkan daya saing mutu artikel ilmiah, meskipun keberadaannya perlu terus dilakukan peningkatan baik dari segi pengelolaannya. Publikasi ilmiah yang perlu disadari akan pentingya secara meluas serta partisipasi dalam membangun jurnal terbitan berkala ilmiah sebagai wadah dalam mengemas, merekam jejak karya seseorang hingga mendesiminasikan hasilnya secara luas. Penulisan draft artikel (manuskrip) akan sangat mempengaruhi isi dan mutu dari artikel ilmiah yang dimuat di jurnal ilmiah yang dikelola oleh Fakultas yang ada di Universitas Muhammadiyah Buton.

Fakultas Keguruan dan Ilmu Pendidikan memiliki tiga prodi yaitu prodi Pendidikan Guru Segu Sekolah Dasar, Pendidikan Bahasa dan Sastra Indonesia, Pendidkan Bimbingan dan Konseling. Fakultas Keguruan dan Ilmu Pendidikan 
memiliki kualifikasi dosen yang memadai, khususnya tim pengabdian kepada masyarakat untuk menyelenggarakan kegiatan pelatihan dan pendampingan penulisan artikel ilmiah untuk mahasiswa Fakultas Keguruan dan Ilmu Pendidikan ini.

Pemanfaatan jurnal ilmiah yang telah ada, yakni yang dikelola oleh fakultas belum menunjukkan hasil dan mutu publikasi secara berkala dengan sebaik-baiknya. Segi pengelolaan perlu ditingkatkan, yang erat kaitannya dengan hal ini adalah penulisan artikel ilmiah oleh mahasiswa. Selama ini artikel yang ditulis oleh mahasiswa dengan dibimbing oleh dosen pembimbing skripsi atau penguji skripsi belum secara utuh memenuhi standar yang ada. Banyak terjadi ketidak sesuaian penulisan yang ditulis mahasiswa. Hal ini pun akan lebih menyusahkan dan terjadinya proses panjang baik bagi mahasiswa maupun pihak pengelola jurnal ilmiah di Fakultas, karena harus mengedit/memperbaiki kembali jurnal yang diajukan oleh mahasiswa tersebut, oleh karena itu, kami tim pengabdian kepada masyarakan mengabdiakan diri untuk membuatan pendampingan dan pelatihan menulis artikel ilmiah agar mahasiswa lebih paham dan mengaerti dalam membuat jurnal Ilmiah.

Tujuan yang ingin dicapai dalam kegiatan pengabdian kepada masyarakat ini ialah agar peserta dapat: (1). memahami tata cara penulisan artikel ilmiah, (2) mampu melakukan penulisan karya ilmiah, (3). memahami kaidah selingkung jurnal ilmiah Fakultas Keguruan dan Ilmu Pendidikan Universitas Muhammadiyah Buton.

\section{B. Masalah}

Permasalahan saat ini adalah masih banyak mahasiswa yang tidak mengetahui cara penulisan artikel ilmiah, dan kaidah selingkung pada jurnal ilmiah Fakultas Keguruan dan Ilmu Pendidikan Universitas Muhammadiyah Buton.

\section{Metode Pelaksanaan}

Berangkat dari identifikasi masalah yang muncul dari analisis khalayak sasaran yang kemudian dirumuskan sebagai masalah yang akan digarap melalui 
pengabdian kepada masyarakat ini, maka diperlukan adanya konsep teori sebagai pendekatan alternatif pemecahan masalah.

Melalui model 'penyebaran' sebagai pendekatan dalam pemecahan masalah, dengan tujuan peserta diperkenalkan secara umum tentang karya ilmiah.

Jumlah peserta dalam kegiatan pelataihan tersebut adalah 115 peserta terdiri dari 3 Prodi yang ada di Fakultas Keguruan dan Ilmu Pendidikan. Pengambilan untuk hasil tes tim menggunakan metode random sampling artinya mengambil hasil tes dengan secara acak yaitu 17 peserta yang dijadikan sampel dalam menguji hasil tes tersebut.Langkah berikutnya adalah proses pemberian teori tentang tata cara penulisan karya tulis ilmiah, selanjutnya dilakukan dengan tugas penulisan dan pendampingan oleh tim pengabdian kepada masyarakat Fakultas Keguruan dan Ilmu Pendidikan Universitas Muhammadiyah Buton.

Khalayak sasaran antara yang dipilih dalam kegiatan pengabdian kepada masyarakat ini adalah mahasiswa Fakultas Keguruan dan Ilmu Pendidikan Universitas Muhammadiyah Buton semester enam. Kegiatan pengabdian kepada masyarakat ini terkait dengan pengembangan pengelolaan jurnal ilmiah yang ada Fakultas Keguruan dan Ilmu Pendidikan . Jurnal Ilmiah merupakan wadah publikasi karya ilmiah mahasiswa sepenuhnya mutu dan isi tersebut terletak pada hasil karya mahasiswa yang kemudian ditulis dalam format ilmiah yang akan dipublikasikan. Oleh karena itu, mahasiswa harus dibina dan diarahkan menurut sistematika penulisan secara ilmiah (selingkung) yang telah ada. Dengan pelatihan penulisan ini, mahasiswa diminta untuk membuat artikel ilmiah dari hasil penelitian skripsi yang telah mengambil skripsi serta dalam proses penyusunan skripsi tidak akan lepas juga dengan penulisan artikel ilmiah yang menyertainya. Tentunya hal ini menjadi langkah dasar dan utama secara umum bagi penulisan artikel dalam bentuk apa pun dan secara khusus artikel ilmiah untuk jurnal yang akan dipublikasikan. Metode yang akan digunakan dalam melaksanakan kegiatan pengabdian kepada masyarakat ini, ialah Ceramah,Tanya jawab, Diskusi, Demonstrasi, Praktek.

Evaluasi keberhasilan kegiatan dirancang (1) Untuk menjajagi seberapa jauh pengetahuan dan wawasan peserta mengenai tata cara penulisan karya 
ilmiah, maka dilakukan pretest kepada para peserta, (2).Untuk mendapatkan gambaran keberhasilan penyampaian ma- teri pengabdian yang telah dilaksanakan, diadakan posttest dan pengamatan sejauhmana peningkatan pengetahuan dan keterampilan peserta tentang penulisan karya ilmiah untuk dipublikasikan.

\section{D.Pembahasan}

Rangkaian pelaksanaan kegiatan pelatihan dan pendampingan penulisan artikel ilmiah untuk jurnal mahasiswa FKIP yang dimulai dari tahap persiapan, sosialisasi dan rekrutmen peserta bulan Juni 2017, persiapan kegiatan dan pengembangan bahan ajar/materi dilaksanakan pada bulan Juli 2017 dan pertemuan/ tatap muka pertama dilaksanakan hari Kamis tanggal 20 Juli 2017, dilanjutkan tatap muka ke dua dilaksanakan hari Jumat tanggal 23 Agustus 2017.

Adapun jumlah peserta yang hadir sebanyak 115 orang, dari jumlah pendaftar 123 orang. Pada saat pelaksanaan kegiatan dilakukan evaluasi yang meliputi pre test dan post test serta pengamatan langsung, dan pengambilan hasiltes kami menggunakan metode random sampling yaitu 17 peserta dan hasilnya dapat dilihat pada tabel di bawah.

\section{PESERTA PREE TEST POST TEST}

PENGAMATAN DI

AKHIR KEGIATAN

1. $\quad 70$

2. $\quad 75$

3. $\quad 70$

$4 . \quad 65$

$5 . \quad 65$

6. 75

$7 . \quad 70$

8. $\quad 75$

$9 . \quad 70$

$10 . \quad 65$

$11 . \quad 70$

12. 75

$13 . \quad 70$

$14 . \quad 75$

$15 . \quad 65$

$16 . \quad 80$
85

90

85

85

80

90

85

85

85

80

80

85

85

90

85

90
Baik

Sangat Baik

Baik

Baik

Baik

Sangat baik

Baik

Sangat Baik

Sangat Baik

Baik

Baik

Baik

Baik

Sangat baik

Baik

Baik 
17. 70

85

Baik

Total

1205

1450

SB: $30 \%$, B:70\%

Naik 20\%

Kegiatan pengabdian kepada masyarakat telah dilakukan sebanyak 2 kali bertempat di gedung aula Universitas Muhammadiyah Buton. Kegiatan Pelatihan dan pendampingan penulisan artikel ilmiah untuk mahasiswa Fakultas Keguruan dan Ilmu Pendidikan Universitas Muhammadiayah Buton telah selesai dilaksanakan dengan hasil yang memuaskan.

Hal ini dapat ditunjukkan adanya tingginya minat peserta untuk ikut kegiatan pelatihan. Adanya peningkatan pengetahuan tentang artikel ilmiah untuk jurnal diukur melalui pre test pada saat pertemuan pertama dan dan post test pada saat pertemuan kedua diperoleh kenaikan rata-rata sebesar $20 \%$.

Penguasaan materi yang dimiliki oleh peserta pada saat akhir pembelajaran diperoleh dari pengamatan diperoleh hasil sangat baik sebanyak 30\% dan kategori baik sebesar 70\%. Hal ini menunjukkan adanya kesungguhan peserta untuk menyerap pengetahuan sebesar-besarnya dari para instruktur.

Adanya pemahaman yang benar tentang artikel ilmiah, terutama yang berkaitan den- gan kajian teori penulisan artikel ilmiah, diharapkan peserta lebih paham dan mengambil langkah-langkah dan tata cara penulisan yang benar seperti yang sudah disampaikan pada kegiatan pengabdian kepada masyarakat ini. Hal ini dapat dilihat pada hasil tugas membuat artikel ilmiah yang dikumpulkan pada sesi kedua. 85\% sudah sesuai dengan teori yang disampaikan pada pertemuan pertama.

Adanya pemahaman yang benar tentang jurnal ilmiah, baik di tingkat Jurusan, ditingkat fakultas, Universitas maupun pada jurnal lembaga lain baik yang sudah terakreditasi maupun yang belum.

Adanya tambahan pengetahuan tentang penulisan artikel ilmiah dan jurnal melalui pelatihan yang diselenggarakan oleh tim pengabdian masyarakat Fakultas Keguruan dan Pengabdian Kepad Masyarakat yang lain- nya, baik dilingkungan sekitar tempat tinggal, dilingkungan tempat belajarnya, maupun dilingkungan 
internal keluarganya sehingga warga masyarakat lain juga dapat mengambil manfaat dari kegiatan pengabdian kepada masyarakat ini.

\section{E. Kesimpulan}

Kegiatan pelatihan dan pendampingan penulisan artikel ilmiah untuk jurnal penelitian mahasiswa Fakultas Keguruan dan Ilmu Pendidikan Universitas Muhammdaiyah Buton telah dilaksanakan dengan hasil baik dengan kenaikan skor rata-rata test sebesar 20\% dan penguasaan teori dengan kategori Sangat Baik sebesar 30\% dan Baik sebesar 70\%., Khalayak sasaran antara yang dipilih dalam kegiatan pengabdian kepada masyarakat ini mempunyai semangat yang tinggi untuk mengikuti semua kegiatan sampai selesai dan dinilai mampu untuk menularkan pengetahuannya pada orang lain. 


\section{DAFTAR PUSTAKA}

Direktorat Jenderal Pendidikan Tinggi. 2012. Buku Panduan Pengelolaan Jurnal Terbitan Berkala Ilmiah Elektronik. Jakarta: Direktorat Jenderal Pendidikan Tinggi Kementerian Pendidikan dan Kebudayaan Republik Indonesia. Peraturan Direktur Jenderal Pendidikan Tinggi Kementerian Pendidikan Nasional Republik Indonesia Nomor 49/Dikti/ Kep/2011 tentang Pedoman Akreditasi Terbitan Berkala Ilmiah.

Maryadi. (2001). Pengertian dan Kriteria Karya Ilmiah. Dalam Harun, dkk. (Eds.), Pembudayaan Penulisan Karya Ilmiah. Surakarta: Universitas Muhammadiyah Surakarta

Nuryadin. (2016). Bahasa Indonesia Untuk Penulisan Karya Ilmiah. Modul (Buku Pegangantar Kuliah), PBSI, Uiversitas Muhammadiyah Buton. 